\title{
Penyusunan peta sastra melalui penelusuran jejak sastra Indonesia sebagai identitas bangsa yang berkarakter
}

\section{Literacy map arrangement through Indonesian literature tracing as nation identity with character}

\author{
Sulaiman', Priyono Tri Febrianto ${ }^{2}$ \\ ${ }^{1}$ Program Studi Pendidikan Bahasa dan Sastra Indonesia \\ ${ }^{2}$ Program Studi Pendidikan Guru Sekolah Dasar \\ Fakultas Ilmu Pendidikan, Universitas Trunojoyo Madura \\ Jalan Raya Telang Po Box 2 Kamal, Bangkalan, Jawa Timur, Indonesia \\ Telepon: (031)3011146 \\ E-mail: lieeman@yahoo.co.id, priyono.febrianto@trunojoyo.ac.id
}

\begin{abstract}
This research departs from various issues related to the definition of literature which always raises debates and dissatisfaction with the existing definition. Literature as national identity also raises debates. Those two reasons had, directly and indirectly, influenced the development of Indonesian map literature. Formation of Indonesian map literature from different periods needed to be clarified so it could provide a clear definition of Indonesian literature development. The aims of this research are (1) constructing Indonesian literature map which explains the development of Indonesian literacy from different periods; and (2) explaining literature as nation identity with character. To analyze the issues, theories and concepts about literature are applied. This research uses descriptive method. Data gathered by descriptive technique and content analysis. The main finding of this research is that there is a significant influence of Indonesian literature development by tracing Indonesian literature to the formation of nation identity with character.
\end{abstract}

Keywords: Indonesian literature, literary maps, character, national identity

\begin{abstract}
Abstrak
Penelitian ini berangkat dari berbagai persoalan yang berkaitan dengan pengertian sastra yang hingga saat ini selalu menjadi bahan pembicaraan dan ketidakpuasan terhadap pengertian yang sudah ada. Di samping itu, keberadaan sastra sebagai identitas kebangsaan juga menjadi perdebatan. Dua hal tersebut, secara langsung maupun tidak sangat mempengaruhi perkembangan peta sastra Indonesia. Bagaimanakah bentuk dan keberadaan peta sastra Indonesia dari masa ke masa juga harus diperjelas sehingga memperjelas perkembangan sastra Indonesia. Tujuan penelitian ini adalah (1) penyusunan peta sastra Indonesia yang memaparkan perkembangan sastra Indonesia dari masa ke masa; dan (2) sastra sebagai identitas kebangsaan yang berkarakter. Untuk mengkaji hal-hal di atas, digunakan beberapa teori dan konsep yang dikemukakan beberapa ahli sastra. Di samping itu, untuk mencapai tujuan penelitian ini, peneliti menggunakan metode deskriptif. Teknik pengumpulan data dengan pengamatan (observasi) dan dokumentasi. Analisis data menggunakan teknik deskripsi dan isi (content analysis). Temuan pokok dalam penelitian ini adalah adanya pengaruh perkembangan sastra Indonesia melalui penelusuran jejak sastra Indonesia terhadap pembentukan identitas bangsa yang berkarakter.
\end{abstract}

Kata kunci: sastra Indonesia, peta sastra, karakter, identitas bangsa

\section{Pendahuluan}

Persoalan peta sastra Indonesia tidak dapat dilepaskan dengan sejarah, baik sejarah bangsa maupun sejarah sastra Indonesia. Sejarah kebangkitan bangsa Indonesia berawal pada abad ke-20 dengan berdirinya Boedi Oetomo sebagai tonggak munculnya kesadaran untuk berorganisasi sebagai usaha membebaskan diri dari cengkeraman penjajah. Organisasi Boedi Oetomo memunculkan nasionalisme untuk menghilangkan perbedaan-perbedaan yang disebabkan oleh perbedaan ideologi, kebudayaan, sosial kemasyarakatan, adat-istiadat, dan kepentingan pribadi atau golongan. Kesadaran itulah yang kemudian melahirkan Sumpah Pemuda, 28 Oktober 1928. Perkembangan tersebut, diikuti pula oleh perkembangan sastra Indonesia sehingga pada tahun 20-an banyak karya sastra yang lahir, terutama berbentuk roman. Begitu halnya pada perkembangan selanjutnya, warna sastra dapat diidentikkan 
dengan sejarah bangsa kita. Bahkan pada perkembangannya, keberadaan sastra sangat dipengaruhi oleh politik. Terjadinya krisis sastra pada tahun 50-an dan 60-an identik dengan krisis yang terjadi pada masa itu. Begitu halnya pada perkembangan sastra di era reformasi.

Para ahli kesusastraan pada umumnya sepakat bahwa tidak mudah untuk merumuskan definisi sastra secara universal. Hal ini terkait dengan latar belakang budaya antara negara yang satu dengan negara lain berbeda. Definisi sastra sangat bergantung pada lingkungan kebudayaan tertentu. Hal ini sejalan dengan pendapat Luxemburg et al. (1992:5) bahwa sastra merupakan sebuah ciptaan, sebuah kreasi, bukan pertama-tama sebuah imitasi. Sang seniman menciptakan sebuah dunia baru, meneruskan proses penciptaan di dalam semesta alam, bahkan menyempurnakannya. Sastra terutama merupakan luapan emosi yang spontan.

Luapan emosi tersebut, secara sadar dituangkan dalam bahasa, khususnya bahasa tulis. Dengan demikian keberadaan sastra tidak dapat dilepaskan dari bahasa. Bahasa merupakan alat bagi sastra. Bahkan bahasa dalam sastra dapat diidentikkan dengan keberadaan bangsa. Darma (1992:1) menyebut sebagai sikap yang tautologis. Sikap tautologis sastra sudah mendarah daging. Disebut sastra Indonesia karena sastra itu milik bangsa Indonesia dan ditulis dengan bahasa Indonesia. Begitu halnya dengan sastra Inggris, Perancis, Jerman, Jepang, Cina, Malaysia, dan bangsa-bangsa lain di dunia karena milik bangsa-bangsa tersebut dan ditulis dengan bahasa nasional bangsa tersebut. Dengan demikian, pertautan bangsa dengan sejarah sastra suatu bangsa tidak dapat dipisahkan keberadaannya. Begitu pula dengan pertautan antara bangsa Indonesia dengan sejarah sastra Indonesia.

Permasalahan penelitian ini adalah persoalan peta sastra Indonesia. Hal ini tidak terlepas dari perkembangan sastra Indonesia, baik puisi, prosa, maupun drama. Perkembangannya cukup pesat, dari sastra Indonesia lama sampai ke sastra Indonesia modern, saat ini. Para pengarangnya pun semakin bertambah banyak. Semakin banyaknya karya sastra Indonesia dan pengarang yang bermunculan, semakin pula isi karya-karya tersebut semakin beragam, baik berkaitan dengan sosial, ekonomi, politik, maupun ideologi. Hal ini sangat dimungkinkan karena sastra adalah ilmu humaniora yang keberadaannya selalu berkembang. Perkembangan sastra, khususnya sastra Indonesia identik dengan gambaran suatu zaman. Setiap zaman memiliki persoalan dan karakteristik yang berbeda-beda. Persoalan dan karakteristik tersebut tergambar dalam karya-karya sastra yang lahir pada masa itu. Di samping itu, perkembangan sastra Indonesia seiring perkembangan bangsa Indonesia.

Permasalahan sastra sebagai identitas kebangsaan juga patut diberi perhatian yang serius. Hal ini berkaitan dengan nilai-nilai atau pesan moral dalam karya-karya sastra Indonesia. Permasalahannya, sudahkah karya-karya sastra Indonesia yang lahir mencerminkan nilai-nilai sebagai identitas kebangsaan Indonesia? Di sisi lain, sastra tidak ubahnya seperti hasil kreasi dan dayacipta manusia, sama seperti hasil ciptaan lainnya, misalnya: lukisan, ukiran, rancang bangun, dan lain-lainnya.

\section{Metode Penelitian}

Penelitian ini bersifat deskriptif. Maolani \& Cahyana (2015:72) menjelaskan bahwa penelitian deskriptif merupakan aktivitas yang bertujuan untuk menggambarkan situasi atau fenomena, yang dirancang untuk mendapatkan informasi dalam keadaan sekarang. Penelitian deskriptif juga untuk mengembangkan tujuan yang luas dari ilmu pengetahuan. Berdasarkan penjelasan tersebut maka metode penelitian deskriptif dalam penelitian ini digunakan untuk mengetahui dan mendalami perkembangan sastra Indonesia. Hal ini berkaitan dengan penyusunan peta sastra Indonesia yang memaparkan perkembangan sastra mulai periodisasi awal hingga saat ini dan sastra sebagai identitas kebangsaan. Desain penelitian ini ditujukan untuk mendeskripsikan suatu keadaan atau fenomenafenomena yang terjadi dalam perkembangan kesusastraan Indonesia. Fakta-fakta ini kemudian akan dianalisis sehingga mencapai sebuah simpulan tentang penyusunan peta sastra Indonesia yang memaparkan perkembangan sastra Indonesia dari masa ke masa dan sastra sebagai identitas kebangsaan yang berkarakter. 
Teknik pengumpulan data yang digunakan dalam penelitian ini adalah pengamatan (observasi) dan dokumentasi. Sugiyono (2013:203) observasi merupakan suatu proses yang kompleks, suatu proses yang tersusun dari berbagai proses biologis dan psikhologis. Dua diantara yang terpenting adalah proses-proses pengamatan dan ingatan. Sementara itu, Nasution (1996:85) teknik dokumentasi merupakan teknik pengumpulan data dengan memanfaatkan sumber dokumen. Berkaitan dengan sumber dokumen dalam penelitian, Sunarto (2001:51) menyatakan bahwa sumber dokumen mempunyai makna penting dalam berbagai jenis penelitian.

Teknik analisis data yang digunakan adalah teknik deskriptif dan isi (content analysis). Supratno (1999:18) menyatakan bahwa analisis deskriptif merupakan teknik analisis data yang mendeskripsikan data apa adanya sehingga dapat menimbulkan kejelasan dan kemudahan bagi pembaca. Moleong (1991:6) memandang analisis deskriptif sebagai suatu teknik pengumpulan data berupa kata-kata, kalimat, serta bukan angka-angka. Teknik ini sangat sejalan dengan penelitian ini karena dalam penelitian ini banyak berisi kutipan-kutipan data untuk memberi gambaran sastra Indonesia mutakhir karya wanita pengarang. Dengan demikian, akan diperoleh banyak data untuk menguatkan analisis dalam penelitian ini. Adapun teknik isi (content analysis) digunakan untuk mendalami setiap isi dalam sastra Indonesia yang menjadi objek pendukung dalam penelitian ini. Krippendroff (1993:5) mengungkapkan bahwa content analysis adalah suatu teknik penelitian untuk membuat "inferensinferens" yang dapat ditiru (repicable) dan sahih dengan memperhatikan konteksnya. Wuradji (2001:6) menyatakan bahwa content analysis berusaha menganalisis dokumen agar diketahui isi dan maknanya, serta digunakan untuk menganalisis peristiwa-peristiwa dan tanda-tanda yang berupa kata-kata maupun kalimat. Adapun tujuannya adalah untuk memperoleh makna dan pemahaman yang mendalam tentang ucapan, pikiran, serta tindakan para tokoh. Selanjutnya, data-data tersebut dianalisis dengan menggunakan tiga prosedur, yaitu: (1) identifikasi, (2) membandingkan, dan (3) aplikasi.

\section{Hasil Penelitian dan Pembahasan}

Secara sederhana dapat dikatakan bahwa sejarah sastra merupakan cabang ilmu sastra yang mempelajari pertumbuhan dan perkembangan sastra suatu bangsa. Dengan pengertian dasar itu, tampak bahwa objek sejarah sastra adalah segala peristiwa yang terjadi pada rentang masa pertumbuhan dan perkembangan suatu bangsa. Telah disinggung di depan bahwa sejarah sastra itu bisa menyangkut karya sastra, pengarang, penerbit, pengajaran, kritik, dan lain-lain.

Luxemburg et al. (1992: 200-212) mengungkapkan bahwa dalam sejarah sastra dibahas periodeperiode kesusastraan, aliran-aliran, jenis-jenis, pengarang-pengarang, dan juga reaksi pembaca. Semua itu dapat dihubungkan dengan perkembangan di luar bidang sastra, seperti sosial dan filsafat. Jadi, sejarah sastra meliputi penulisan perkembangan sastra dalam arus sejarah dan di dalam konteksnya. Perhatian para ahli sastra di Eropa terhadap sejarah sastra muncul pada abad ke-19, berawal dari perhatian ilmuwan pada zaman Romantik yang menghubungkan segala sesuatu dengan masa lampau suatu bangsa. Adapun dasarnya adalah filsafat positivisme yang bertolak pada prinsip kausalitas, yaitu segala sesuatu dapat diterangkan bila sebabnya dapat dilacak kembali. Dalam hal sastra, sebuah karya sastra dapat diterangkan atau ditelaah secara tuntas apabila diketahui asalusulnya yang bersumber pada riwayat hidup pengarang dan zaman yang melingkunginya.

\section{Periodisasi sejarah sastra Indonesia}

Masalah periodisasi sejarah sastra Indonesia secara eksplisit telah diperlihatkan oleh Rosidi (1998) dalam Ikhtisar Sejarah Sastra Indonesia, Sumardjo (1992) dalam Lintasan Sejarah Sastra Indonesia 1, dan Pradopo (1995a) dalam Beberapa Teori Sastra, Metode Kritik, dan penerapannya. 
Secara garis besar Rosidi (1998:13) membagi sejarah sastra Indonesia, seperti pada tabel 1.

Tabel 1.

Periodisasi Sejarah Sastra Indonesia

\begin{tabular}{lll}
\hline I & Masa Kelahiran atau Masa & 1) Period Awal hingga 1933 \\
& & 2) Period 1933-1942 \\
& & 3) Period 1942-1945 \\
\hline II & Masa Perkembangan 1945-1968 & 1) Period 1945-1953 \\
& & 2) Period 1953-1961 \\
& 3) Period 1061-1968 \\
\hline
\end{tabular}

Periodisasi di atas sudah tidak bisa mengikuti perkembangan sastra Indonesia yang terus berkembang hingga saat ini. Di samping itu, periodisasi di atas sangatlah sederhana karena hanya dibagi menjadi dua bagian, yaitu Masa Kelahiran atau Kebangkitan (1900-1945) dan Masa Perkembangan (19451968). Pada periode awal juga tidak ada kejelasan kelahiran sastra Indonesia. Di samping itu, sejak tahun 1933 sastra Indonesia mengalami perkembangan yang luar biasa, terutama masalah tema yang tidak lagi terbelenggu oleh tema-tema sebelumnya, yaitu kawin paksa. Apalagi pada tahun 1945 dengan puisi-puisi Chairil Anwar yang dapat dikatakan sebagai pembaharu corak sastra Indonesia, khususnya pada sajak. Setelah penelitian Rosidi (1998) yang melahirkan buku Ikhtisar Sejarah Sastra Indonesia belum banyak peneliti sastra yang membicarakan periodisasi sastra Indonesia, padahal sastra terus berkembang sejalan dengan perkembangan kehidupan berbangsa dan bernegara.

Berdasarkan hasil penelitian, kajian, dan penelusuran data, peneliti mengemukakan konsep periodisasi sejarah sastra Indonesia berdasarkan perubahan warna sastra Indonesia yang dipengaruhi oleh sosial, budaya, dan politik, yaitu: Angkatan 20 (Balai Pustaka), Angkatan 33 (Pujangga Baru), Angkatan 45 (Perjuangan), Angkatan 66 (Pergolakan), Angkatan 80 (Romantisme), dan Angkatan 98 (Reformasi).

\section{Angkatan 20 (balai pustaka) dan identitas kebangsaan}

Mendalami sastra Indonesia, tidak akan dapat melepaskan peranan Angkatan Balai Pustaka. Meski pendirian Angkatan ini pada tahun 1917 atas inisiatif Pemerintah Belanda di Indonesia (sebagai negeri jajahan). Boleh dikatakan karya-karya sastra yang lahir pada angkatan ini merupakan cikal bakal lahirnya sastra Indonesia. Bahkan beberapa karya sastra yang dominan berbentuk roman tersebut hingga sekarang masih akrab dengan kita. Roman Azab \& Sengsara (1920) karya Merari Siregar, Siti Nurbaya (1922) karya Marah Rusli, Muda Teruna (1922) karya M. Kasim, Salah Asuhan (1928) karya Abdoel Moeis, Salah Pilih (1928) karya Nur Sutan Iskandar, Tak Putus Dirundung Malang (1929) karya Sutan Takdir Alisyahbana, dan masih banyak lagi. Khusus Siti Nurbaya dianggap sebagai roman terbaik pada Angkatan Balai Pustaka. Meskipun hampir semua penceritaan bertemakan kawin paksa, tetapi di dalamnya tersirat rasa nasionalisme. Melalui karakter Datuk Maringgi dalam Siti Nurbaya rasa nasionalisme disiratkan dengan ketidakmauan tokoh ini untuk bekerjasama dengan Belanda. Datuk Maringgi adalah tokoh anti-Belanda. Baginya, ia bebas menentukan jalan hidupnya sendiri.

Perkembangan selanjutnya, tidak hanya terbatas pada roman saja. Pada Angkatan Balai Pustaka (20-an), khasanah sastra kita telah berkembang hingga melahirkan beberapa bentuk puisi (sajak). Pengarang yang sangat berperan dalam persajakan adalah Muh. Yamin dan Roestam Effendi. Muh. Yamin menulis sajak sembilan seuntai yang berjudul Tanah Air (1922). Di samping itu, Muh. Yamin juga menulis beberapa soneta. Sebagian besar sajak-sajak Muh. Yamin berupa lirik yang berisi rasa bangga terhadap tanah airnya (Indonesia). Sajak Bangsa, Bahasa (1922) yang ditulisnya melukiskan betapa pentingnya bahasa bagi bangsa. Tanpa bahasa maka suatu bangsa tidak memiliki identitas. Ia juga menulis sajak Indonesia, Tumpah Darahku (1928). Sajak ini diterbitkan bertepatan dengan Sumpah Pemuda, 28 Oktober 1928. Sementara itu, Roestam Effendi menulis dua buah buku, yaitu: Bebasari dan Percikan Permenungan. Bebasari merupakan sebuah drama-bersajak, sedangkan Percikan Permenungan merupakan kumpulan sajak. 
Nilai-nilai identitas kebangsaan juga tampak pada drama-bersajak Bebasari yang ditulis Roestam Effendi. Di dalam naskah drama ini diceritakan tentang perjuangan seorang pemuda yang membebaskan kekasihnya dari cengkeraman keserakahan raksasa (Rosidi 1998:20). Keberadaan raksasa dalam naskah drama tersebut dapat diidentikkan dengan penjajah, Belanda. Seorang kekasih identik dengan bangsa Indonesia yang ingin lepas dari cengkeraman penjajah.

Hal ini menunjukkan bahwa dalam karya-karya sastra Indonesia pada Angkatan 20, meskipun tidak secara terang-terangan sudah menyiratkan identitas kebangsaan. Keinginan untuk merdeka, menjadi tumpah darah yang berdaulat sudah disuarakan melalui karya-karya sastra Indonesia pada masa itu. Hal itu merupakan wujud dari cinta tanah air dan perjuangan untuk melepaskan diri dari belenggu kekuasaan penjajah.

\section{Angkatan 33 (pujangga baru) dan identitas kebangsaan}

Pada perkembangan selanjutnya, tema-tema kesusastraan Indonesia tidak hanya sebatas pada kawin paksa, sebagai tradisi memarginalkan perempuan, pada masa itu. Kesusastraan Indonesia terpengaruh oleh budaya Barat. Sastrawan yang paling berperan dalam hal ini adalah Sutan Takdir Alisyahbana (STA). Sebagai bentuk pembaharuan, didirikanlah majalah Poedjangga Baroe pada tahun 1933 yang juga diidentikkan dengan nama Angkatan 30-an. Beberapa karya satra yang lahir pada Angkatan ini adalah: Dian Yang Tak Kunjung Padam (1932), Layar Terkembang (1936) karya STA; Belenggu (1940) karya Armijn Pane; Hulubalang Raja (1934) dan Katak Hendak Jadi Lembu (1935) karya Nur Sutan Iskandar; Sukreni Gadis Bali (1936) karya I Gusti Njoman Pandji Tisna; Percobaan Setia (1931) dan Kawan Bergelut (1938) karya Suman Hasibuan; dan lain-lain.

Layar terkembang dianggap sebagai roman yang terbaik pada angkatan ini. Melalui tokoh 'Tuti', STA mengungkapkan gagasan-gagasan dan pandangan-pandangannya tentang emansipasi wanita. Tokoh 'Tuti' lebih mementingkan harkat dan martabat perempuan yang harus dijunjung tinggi. Hidup perempuan tidak boleh dikuasai atau bertekuk lutut di bawah kekuasaan laki-laki. Usaha pembebasan harkat dan martabat perempuan terlihat nyata. Perempuan tidak dipandang lagi sebagai sosok yang termarginalkan. Kedudukan perempuan sama pentingnya dengan laki-laki. Perempuan juga boleh bercita-cita seperti laki-laki atau bahkan melebihinya. Hal itu sangat tampak pada tokoh Tuti yang menerangkan pengaruh seorang ibu dalam mendidik anak-anaknya sampai berhasil meraih citacitanya. Bahwa perempuanlah yang pertama kali memimpin anak dan menetapkan sifat-sifat yang mulia yang seumur hidup tidak berubah lagi dalam jiwa anak (Alisyahbana 2006:47). Pada bagian lain dijelaskan pula bahwa sesungguhnyalah hanya kalau perempuan dikembalikan derajatnya sebagai manusia, barulah keadaan bangsa kita dapat berubah. Jadi, perubahan kedudukan perempuan dalam masyarakat itu bukanlah semata-mata kepentingan perempuan (Alisyahbana 2006:47). Berdasarkan hal tersebut juga menyiratkan identitas kebangsaan berupa kesadaran akan pendidikan. Kesadaran untuk menuntut ilmu setinggi-tingginya. Hal ini tidak hanya berguna bagi dirinya sendiri, tetapi juga berguna bagi masyarakat, bangsa, dan negara.

Dalam perkembangan selanjutnya, bermunculan para perempuan pengarang. Meskipun jumlahnya tidak banyak, tetapi kehadiran mereka turut mewarnai penceritaan pada masa itu. Di antara mereka yang paling terkenal dan dianggap penting adalah Selasih (juga menggunakan nama samaran Seleguri dan Sariamin). Dia menulis roman Kalau Tak Untung (1933) dan Pengaruh Keadaan (1937). Umumnya tema-tema pada masa itu, masih bergulat pada romantisme. Begitu halnya dengan Kalau Tak Untung (1933). Perempuan pengarang pada masa ini, selain Selasih yang juga mengarang roman adalah Hamidah. Pengarang yang konon merupakan nama samaran Fatimah H. Delais (Rosidi 1998:54) menulis sebuah roman Kehilangan Mestika (1935).

\section{Angkatan 45 (perjuangan) dan identitas kebangsaan}

Istilah Angkatan Perjuangan adalah identik dengan Angkatan 45, sebuah nama bagi Angkatan (penyair) setelah mulai pudarnya eksistensi periode Pujangga Baru. Istilah Angkatan 45 sendiri secara 
lugas baru digunakan pertama kali oleh Rosihan Anwar dalam majalah Siasat yang diterbitkan pada tanggal 9 Januari 1949 (Teew dalam Nursasongko 2008:1). Pradopo dalam (Nursasogko 2008:1) menyebutkan bila Angkatan 45 dimulai dari tahun 1940 dan berakhir tahun 1955. Konsepsi Angkatan 45 tertuang dalam Surat Kepercayaan Gelanggang yang menjadi pandangan pokok para pengarang Angkatan 45. Waluyo (1987:58) mengemukakan tiga pokok pikiran yang terkandung dalam Surat Kepercayaan Gelanggang itu, yaitu: (1) Bahwa para sastrawan merupakan ahli waris yang sah dari kebudayaan dunia; (2) Ciri keindonesiaan tidak ditandai oleh wujud fisik, tetapi terlebih oleh ungkapan jiwa, kebudayaan Indonesia terjadi oleh pengaruh dari luar dan perkembangan dari dalam. Jadi tidak usah menyebut keaslian yang mempersempit ukuran dan nilai; dan (3) Revolusi adalah penempatan nilai baru atas nilai lama yang usang.

Berdasarkan isi surat di atas dapat dilihat identitas kebangsaan kita, khususnya ciri keindonesiaan sebagai bentuk nasionalisme dan revolusi sebagai pembaruan sikap dan tindakan dalam berkarya. Hal itu dapat dilihat pada karya Idrus, yaitu Coret-coret di Bawah Tanah yang mengisahkan kehidupan rakyat di zaman penjajahan Jepang. Ada semangat nasionalisme dan patriotisme dari rakyat untuk membebaskan diri dari penjajahan Jepang. Rosidi (1998:96) menjelaskan bahwa sikap sinis dan kasar Idrus diperlihatkannya pula ketika ia menulis tentang para pejuang kemerdekaan menghadapi pasukan-pasukan Inggris dan Belanda yang mau menjajah lagi Indonesia dalam karangannya yang berjudul Surabaya. Begitu halnya dalam Keluarga Gerilya karya Pramudya Ananta Tour (Pram). Pram tidak hanya sekadar mengisahkan penderitaan tokoh utamanya, yaitu Saman dan Amilah. Lebih jauh, ia menyadarkan pentingnya mempertahankan kemerdekaan bangsa Indonesia yang telah diraih dengan pengorbanan yang besar. Identitas kebangsaan ini melekat pada karya-karya sastra Indonesia pada masa itu. Memiliki tujuan yang sama, yaitu memperjuangkan dan mempertahankan kemerdekaan Indonesia. Hal ini sangat tampak pada puisi-puisi Chairil Anwar, seperti Aku, Diponegoro, dan Karawang Bekasi; Puisi Mantera oleh Asrul Sani, dan Kebebasan sebuah puisi Rivai Apin. Berdasarkan hal-hal tersebut tepatlah kalau angkatan ini identik dengan Angkatan Perjuangan.

Pengalaman hidup dan gejolak sosial-politik-budaya telah mewarnai karya sastrawan Angkatan 45 (Agni 2009:18). Angkatan 45 lahir dalam suasana lingkungan yang sangat prihatin dan serba keras, yaitu lingkungan fasisme Jepang dan dilanjutkan peperangan mempertahankan kemerdekaan Indonesia. Masa Angkatan 45, benar-benar terjadi revolusi dalam puisi. Ikatan puisi lama sudah ditinggalkan. Pada Angkatan 45 yang dipentingkan adalah makna atau bentuk batin puisi, ikatan bentuk fisik puisi tidak dominan lagi. Perbedaan yang mencolok terletak pada pemakaian bahasa dan tema yang diangkat. Sajak-sajak Chairil sangat menunjukkan penggunaan bahasa Indonesia yang membedakan dengan bahasa Melayu. Begitu halnya dengan tema yang diangkat berbeda dengan tema-tema karya sastra sebelum merdeka. Menurut Ambary (1994:90) pandangan penulis dalam bentuk-bentuk karangan lebih bebas dari AngkatanPujangga Baru, sedangkan dalam isi, Angkatan 45 bercorak realistis.

Selain Chairil Anwar, Asrul Sani dan Rivai Apin merupakan tokoh penting dalam persajakan Angkatan 45. Asrul Sani mendirikan 'Gelanggang Seniman Merdeka'. Sebagian besar sajak-sajak Asrul termuat dalam Tiga Menguak Takdir dan Gema Tanah Air (1948) yang disusun H.B. Jassin. Sajak-sajak Asrul Sani dikenal sangat lugas dan menunjukkan pandangan hidupnya yang moralis. Rivai Apin merupakan salah satu tokoh penting dalam persajakan pada masa ini. Sajak-sajak Rivai Apin sarat dengan permasalahan. Dalam sajak Kebebasan, penyair meggambarkan kebebasan dirinya dalam menghadapi permasalahan-permasalahan yang dihadapi.

Selain ketiga penyair tersebut, masih terdapat dua nama yang turut mewarnai khasanah persajakan sesudah merdeka, yaitu Sitor Situmorang. Sitor Situmorang kali pertama menerbitkan kumpulan sajak Surat Kertas Hijau (1954). Kumpulan sajak ini terdiri atas dua kumpulan sajak Surat Kertas Hijau dan Orang Asing. Berikutnya, disusul kumpulan sajak kedua yang berjudul Dalam Sajak (1955), Wajah Tak Bernama (1956) dan Zaman Baru (1962). Menurut Rosidi (1998:107) gaya sajak Sitor yang lincah dan merdu kecuali memberikan udara baru bagi iklim persajakan Indonesia yang pada saat-saat itu tenggelam dalam sajak-gelap, juga memberikan pengaruh kepada banyak penyair lain, 
terutama yang muda-muda. Hal itu menunjukkan adanya identitas kebangsaan berupa keteladanan. Keteladanan itu penting sebagai usaha untuk mencapai tujuan hidup yang dicita-citakan.

Karya terbesar dan identik dengan identitas kebangsaan pada Angkatan ini adalah puisi-puisi Chairil Anwar, yaitu Aku, Diponegoro, dan Karawang Bekasi. Puisi Chairil Anwar yang mencerminkan sikap pantang menyerah, rasa kebangsaan dan patriotisme adalah Aku, Diponegoro dan Karawang Bekasi. Apabila dilihat secara sekilas puisi Aku menggambarkan keegoisan pengarangnya. Hal itu terlihat pada larik "Aku ini binatang jalang". Padahal, larik tersebut dapat diapresiasi sebagai dorongan kata hati rakyat Indonesia untuk bebas merdeka. Merdeka menentukan nasibnya sendiri tidak bergantung pada campur tangan bangsa lain.

Begitu halnya dalam Diponegoro (1943). Puisi ini juga menggambarkan identitas kebangsaan sebagai bentuk perjuangan dan semangat untuk meraih kemerdakaan. Puisi ini menghidupkan kembali semangat perjuangan dalam melawan penjajah pada saat itu melalui tokoh pahlawan nasional, Pangeran Diponegoro. Pada larik "Di masa pembangunan ini Tuan hidup kembali" tidak dimaknai sebagai kehidupan sesudah kematian Pangeran Diponegoro. Larik tersebut dimaknai untuk membangun semangat rakyat Indonesia agar gigih berjuang merebut kemerdekaan dari penjajah.

Dalam puisi Karawang Bekasi (1948) Chairil Anwar seolah menegaskan kembali arti penting sebuah perjuangan. Larik "Kami yang kini terbaring antara Krawang-Bekasi" bermakna banyaknya pejuang yang telah gugur di medan pertempuran. Penggambaran suatu peristiwa yang telah terjadi di daerah sepanjang Karawang--Bekasi, dan peristiwa tersebut merupakan pengorbanan dan usaha para pejuang berserta warga sekitar Karawang Bekasi dalam mempertahankan kemerdekaan, meskipun mereka harus mati muda. Jiwa patriotisme sangat tampak dalam puisi tersebut. Inilah nilai-nilai terpenting yang dapat dijadikan teladan bagi generasi muda sebagai identitas kebangsaan.

\section{Angkatan 66 (pergolakan) dan identitas kebangsaan}

Kenyataan sejarah membuktikan bahwa sejarah awal pertumbuhan sastra Indonesia, para pengarang sudah menunjukkan perhatian yang cukup serius terhadap dunia politik. Nama Angkatan 66 kali pertama digunakan Jassin dalam Angkatan 66: Prosa dan Puisi. Dalam buku ini, H.B. Jassin menyampaikan penolakannya terhadap Angkatan 50 dengan mengutip pernyataan Ajip Rosidi dalam Simposium Sastra Pekan Kesenian Mahasiswa di Jakarta pada tanggal 14 Agustus 1960. Jassin mengkritisi semua konsepsi-konsepsi Angkatan 50 dan Angkatan terbarunya Ajip Rosidi dengan nada emosional dan keras. Alasan utama penafsiran Angkatan 50 dan Angkatanterbaru adasah kedekatan masa dengan Angkatansebelumnya yaitu Angkatan 45 sehingga tidak ada konsep yang berlainan dengan Angkatansebelumnya tersebut (Jassin 2013:17-18).

Pada periodesasi ini terjadi pergolakan yang hebat antara dua kubuh, yaitu pengarang-pengarang yang tergabung dalam Lembaga Kebudayaan Rakyat (Lekra) dan Manifes Kebudayaan. Mereka saling menyerang dan menjatuhkan. Bahkan oleh Lekra, pengarang-pengarang dalam Manifes Kebudayaan disebut "manikebu" (Rosidi 1998:168), suatu sebutan yang sangat hina. Lekra mengusung paham realisme-sosialis yang menjadi filsafat seni kaum komunis. Paham ini mendudukkan 'seni untuk rakyat'. Sementara itu, pengarang-pengarang Manifes Kebudayaan mengusung paham humanisme universal yang mendudukkan 'seni untuk seni'. Pergolakan ini dipicu oleh persoalan politik masa itu. Orang-orang Lekra memanfaatkan kekuatan PKI sebagai partai terbesar pada saat itu, sehingga menguasai pemerintahan. Lekra juga demikian, mereka menguasai penerbitan-penerbitan dan tidak segan-segan menyerang dan menghancurkan media-media yang dijadikan sarana berekspresi pengarang-pengarang Manifes Kebudayaan. Meskipun demikian, masih ada keberanian untuk melawannya. Hal ini terlihat dari drama Domba-domba Revolusi (1962) yang ditulis B. Soelarto. Dalam Domba-domba Revolusi digambarkan oleh tiga tokoh dalam satu babak, para pelakunya, yaitu: perempuan, penyair, dan pedagang yang terdampar pada sebuah losmen di kota yang sedang dikepung tentara Belanda dan hampir direbut pada tahun 1948. Pedagang di sini digambarkan sebagai seorang yang licik, oportunistik, pemeras, memunyai niat buruk, dan mengambil keuntungan dari 
revolusi kemerdekaan. Mereka hanya memikirkan keselamatan dirinya sendiri. Perempuan pemilik losmen adalah tokoh baik-baik, tetapi terpaksa membunuh juga demi keselamatannya. Hanya penyairlah yang paling dianggap benar, berani, suci seolah menjadi perlambang cita-cita revolusi tersebut (Soelarto 1964:99).

Meletusnya pemberontakan G30S/PKI dan ditangkapinya orang-orang PKI membawa angin terbalik pada orang-orang Manifes Kebudayaan. Para pengarang Manifes Kebudayaan yang selama beberapa kurun waktu tertindas menjadi orang-orang yang bebas dalam berekspresi. Mereka mengadakan perlawanan melalui karya-karyanya. Di antaranya yang paling mencolok adalah Tirani (1966) dan Benteng (1968) yang ditulis Taufik Ismail. Sajak-sajak yang ditulis Taufik Ismail sangat bersentuhan dengan peristiwa-peristiwa pada masa itu. Bahkan peristiwa terbunuhnya Arif Rahman Hakim (Pahlawan Ampera) diapresiasikannya dalam sajak Karangan Bunga.

Sajak Karangan Bunga menggambarkan keprihatinan masyarakat kecil. Puisi tersebut menceritakan tentang keharuan dan rasa duka yang disampaikan oleh anak-anak kecil yang bersimpati terhadap nasib kakak-kakaknya yang telah ditembak mati. Sebuah puisi dapat menyiratkan sebuah makna, baik hubungan makna antarbait maupun antarlarik. Peristiwa itu terjadi akibat pergolakan mahasiswa yang tidak puas dengan pemerintahan pada masa itu. Identitas kebangsaan yang tersirat dalam puisi tersebut adalah rasa nasionalisme. Nasionalisme mahasiswa sebagai bentuk kepedulian untuk menyuarakan masyarakatnya yang menjadi korban akibat krisis politik dan ekonomi pada masa itu sehingga banyak rakyat kecil yang menderita.

Pada masa ini juga melahirkan beberapa perempuan pengarang. Di antara mereka yang paling menonjol adalah N.H. Dini. Dia aktif menulis sejak tahun 50-an dengan melahirkan kumpulan cerpen Dua Dunia (1956). Dalam cerpen-cerpennya, Dini menaruh perhatian yang besar terhadap kepincangan-kepincangan kehidupan sosial yang terjadi di sekitarnya. Setelah itu, ia melahirkan novel Hati yang Damai (1961). Perjalanannya ke Jepang melahirkan Namaku Hiroko kemudian Pada Sebuah Kapal. Tokoh lain yang tidak kalah pentingnya adalah Titie Said. Ia menulis cerpen dan dibukukannya dalam Perjuangan dan Hati Perempuan (1962). Nama lainnya adalah: S. Tjahjaningsih menulis kumpulan cerpen Dua Kerinduan (1963); Sugiarti Siswadi menulis kumpulan cerpen Sorga di Bumi (1960); Enny Sumargo menulis novel Sekeping Hati Perempuan (1969), dan beberapa penyair.

Masih banyak pengarang dan penyair Angkatan 66 lainnya yang mempunyai andil besar dalam mempertahankan Pancasila, antara lain: N.H. Dini yang aktif menulis sejak tahun 50-an dengan melahirkan kumpulan cerpen Dua Dunia (1956). Dalam cerpen-cerpennya, Dini menaruh perhatian yang besar terhadap kepincangan-kepincangan kehidupan sosial yang terjadi di sekitarnya. Taha Mochtar, Arifin C. Noer, Bokor Hutasuhut, Bur Rasuanto, Ayip Rosidi, W.S.Rendra, Iswi Sawitri, Abdul Wahid, Situmcang, Satyagraha Hocrip, Masnur Samin, Subagio Sastro Wardoyo, dan lainlainnya. Mereka dapat digolongkan pejuang dalam membela negara untuk tetap tegaknya Pancasila dan UUD 45 melalui karya-karyanya.

\section{Angkatan 80 (romantisme) dan identitas kebangsaan}

Runtuhnya kekuasaan politik PKI menandai runtuhnya orde lama dan bergantilah pada orde baru dengan duduknya Soeharto sebagai presiden menggantikan Soekarno. Pada era ini terkenal dengan sebutan Orde Pembangunan. Hal ini juga berdampak pada perkembangan sastra Indonesia. Sastra Indonesia semakin menemukan warnanya. Budi Darma memberikan warnah filsafat pada karyakaryanya, seperti: Rafilus dan Olenka. Hal ini juga terjadi pada novel-novel Iwan Simatupang. Danarto, Abdul Hadi W.M., dan Soetardji Calzoum Bahri memberikan warna mistik. Mangun Wijaya, Umar Kayam, dan Ahmad Tohari sangat kental dengan warna kedaerahan (budaya lokal). Warna ideologi sangat kental dengan karya-karya Emha Ainun Nadjib, seperti Lautan Jilbab (1989) dan Slilit Sang Kiai (1991). 
Perkembangan sastra Indonesia tahun 1980-1990-an tidak terlepas dari warna-warna tadi khususnya warna budaya lokal. Ahmad Tohari melalui trilogi novelnya: Ronggeng Dukuh Paruk (1982), Lintang Kemukus Dini Hari (1985), dan Jentera Bianglala (1986); Linus Suryadi A.G. menulis Pengakuan Pariyem (1981); Y.B. Mangun Wijaya menulis novel Burung-burung Manyar (1981) kemudian disusul Burung-burung Rantau (1992); Ramadhan K.H. menulis dalam bentuk novel Ladang Perminus (1990); Putu Wijaya menulis Teror (1991) dan beberapa dalam bentuk drama; dan Umar Kayam dengan Para Priyayi (1992). Beberapa karya lainnya adalah: Sri Sumarah, Bawuk, Mangan Ora Mangan Kumpul, Sugih Tanpa Banda, dan Madhep Ngalor Sugih Madhep Ngidul Sugih.

Dari sekian karya Umar Kayam yang dianggap fenomenal adalah Para Priyayi. Novel ini menghadirkan persoalan sebutan priyayi bagi masyarakat Jawa. Kaum priyayi yang identik dengan orang-orang yang terhormat dari keturunan bangsawan digugatnya dengan sosok Soedarsono. Berasal dari keluarga buruh tani, Soedarsono, oleh orang tua dan sanak saudaranya dapat diharapkan membangun dinasti priyayi bagi keluarga kecil itu. Akhirnya, ia pun berhasil membangun keluarga priyayi. Ia tumbuh menjadi priyayi pangreh praja. Akan tetapi, anak cucunya tidak berhasil mempertahankannya. Justru Lantip, anak jadah dari keponakan jauhnya, yang tampil sebagai priyayi yang sesungguhnya. "Anak jadah ini tumbuh sebagai anak yang sungguh baik dan amat berbakti kepada semua keluarga kami (Kayam 2001:233)". Dalam hal ini terlihat sikap patuh dan hormat pada keluarga, juga menjadi kebanggaan keluarga. Hal-hal tersebut juga merupakan identitas kebangsaan yang perlu ditumbuhkembangkan dan selalu dijaga keberadaannya.

Begitu halnya apabila kita menyimak Ronggeng Dukuh Paruk karya Ahmad Tohari. Persoalan adat dan budaya yang telah mengakar ditentangnya. Budaya seorang ronggeng yang dianggap manusia suci ditentangnya. Hal inilah yang menyebabkan terjadinya pertentangan antara golongan terpelajar yang berpikir rasional dan golongan para tetua yang masih memegang adat. Seperti terlihat dalam petikan:"Entah sampai kapan pemukiman sempit dan terpencil itu bernama Dukuh Paruk. Kemelaratannya, keterbelakangannya, penghuninya yang kurus dan sakit, serta sumpah serapah cabul menjadi bagiannya yang sah (Tohari 2004:79).

Karya sastra di Indonesia pada kurun waktu setelah tahun 1980, ditandai dengan banyaknya roman percintaan, dengan sastrawan wanita yang menonjol pada masa tersebut, yaitu Mira W dan Marga $\mathrm{T}$, dua sastrawan perempuan Indonesia yang menonjol dengan fiksi romantis. Pada umumnya, tokoh utama dalam novel mereka adalah perempuan dengan segala problematikanya. Karya sastra Indonesia pada masa Angkatan ini tersebar luas di berbagai majalah dan penerbitan umum. Beberapa sastrawan yang dapat mewakili Angkatan dekade 1980-an ini antara lain adalah: Remy Sylado, Yudistira Ardinugraha, Noorca Mahendra, Seno Gumira Ajidarma, Pipiet Senja, Kurniawan Junaidi, Ahmad Fahrawie, Micky Hidayat, Arifin Noor Hasby, Tarman Effendi Tarsyad, Noor Aini Cahya Khairani, dan Tajuddin Noor Ganie.

\section{Angkatan 98 (reformasi) dan identitas kebangsaan}

Lahirnya Angkatan 98 tidak bisa dilepaskan dari kondisi sosial dan politik yang terjadi pada akhir tahun 1990-an, seiring dengan jatuhnya Orde Baru. Proses reformasi politik yang dimulai pada tahun 1998 banyak melatarbelakangi kelahiran karya-karya sastra puisi, cerpen, dan novel pada saat itu. Sastra Reformasi adalah masa ketika karya-karya sastra Indonesia muncul pada masa sekitar era reformasi (beberapa tahun sebelum 1998 sampai sekarang) yang tentu saja sangat dipengaruhi oleh semangat reformasi yang sedang marak digembar-gemborkan pada saat itu. Semangat reformasi tersebut menuntut adanya kebebasan untuk menyuarakan pendapat individu, yaitu kebebasan dalam berkreativitas sastra.

Sejak reformasi 1998, mengalirnya semangat kebebasan semakin deras. Semangat ini akhirnya menabrak norma-norma yang berlaku sebelumnya. Hal-hal yang dianggap tabu seperti masalah seks dan kelamin malah marak diperbincangkan. Bahkan yang bersuara lantang dan mengekspos jati diri perempuan dengan segala sesuatu yang dimiliki, termasuk mengekploitasi bagian tubuh yang 
menurut sebagaian orang dianggap tabuh. Penggunaan kosakata seputar alat kelamin (kemaluan), perilaku seks, gambaran tubuh perempuan dan bagian-bagian pakaian yang menutupi tubuhnya seakan menjadi sesuatu yang wajar. Meskipun demikian, kehadiran mereka turut mewarnai khasanah sastra Indonesia, terutama menjadikan perempuan dan eksistensinya sebagai sumber ide dalam penceritaan. Di antara mereka adalah: Ayu Utami (Ayu), Dewi Lestari (Dee), Fira Basuki (Fira), Nova Riyanti Yusuf (Nova), Oka Rusmini (Oka), Herlinatiens, Djenar Maesa Ayu (Djenar), Rieke Diah Pitaloka (Rieke), Ratih Kumala (Ratih), Dewi Sartika (Dewi), Abidah El Khalieqi (Abidah), dan lain-lain.

Melihat fenomena tersebut, tidak dapat dipungkuri ada anggapan kurang baik terhadap meraka. Akan tetapi, ada sisi yang lebih utama, yaitu eksistensi mereka. Eksistensi perempuan pengarang sastra Indonesia. Eksistensi inilah yang menunjukkan sikap pantang menyerah, sikap gigih memperjuangkan hak-haknya, dan sikap kemandirian sebagai seorang perempuan. Tentunya ini sangat berkaitan untuk semakin memperkuat identitas kebangsaan sebagai manusia yang berdikari. Melihat kekuatan dan kreativitas para perempuan pengarang di atas, Damono (dalam Srengenge, 2004:84) mengatakan bahwa tanpa harus memberikan peringkat ke-sastra-an atau ke-populer-an (seolah-olah keduanya dapat dibedakan), di masa mendatang mungkin perkembangan sastra kita akan ditentukan oleh perempuan.

Dalam perjalanan sastra Indonesia, periode reformasi merupakan masa paling semarak dan luar biasa. Kini, karya-karya sastra terbit seperti berdesakan dengan tema dan pengucapan yang beraneka ragam. Faktor utama yang memungkinkan sastra Indonesia berkembang seperti itu, tentu saja disebabkan oleh perubahan yang sangat mendasar dalam sistem pemerintahan. Kehidupan pers yang terkesan serba bebas dan serba boleh ikut mendorong terjadinya perkembangan itu. Maka, kehidupan sastra Indonesia seperti berada dalam pentas terbuka. Di sana, para pemainnya seolah-olah boleh berbuat dan melakukan apa saja.

Selain pengarang-pengarang di atas, ada dua nama yang cukup menggemparkan dunia sastra pada dekade ini melalui karya-karyanya, yaitu Andrea Hirata dan Habiburrahman El Shirazy. Karya-karya mereka tidak sekadar berupa novel yang diterjemahkan ke dalam berbagai bahasa internasional, juga menarik dunia sineas untuk diangkat ke layar lebar.

Andrea Hirata yang memiliki nama lengkap Andrea Hirata Seman Said Harun menulis novel Laskar Pelangi yang merupakan buku pertama dari tetralogi novelnya, yaitu: Laskar Pelangi, Sang Pemimpi, Edensor, dan Maryamah Karpov. Novel Laskar Pelangi dapat dijadikan simbol keemasan pada masa ini. Dalam novel ini dilukiskan penggambaran perjuangan seorang guru dalam membangkitkan semangat pendidikan di sebuah SD yang serba kekurangan secara fisik. Hal ini menyiratkan bahwa kemiskinan dan kekurangan fasilitas pendidikan bukanlah suatu hal yang menghambat terpuruknya seseorang untuk menempuh ilmu dan mempunyai pandangan buruk tentang keadaan tentang serba sederhana. Semangat dan pandangan hidup kedepan akan membuat seseorang mampu melampaui masa sulit dalam menempuh pendidikan.

Melalui tokoh Lintang digambarkan perjuangan seorang anak nelayan yang memiliki tekad kuat untuk bersekolah. Meskipun banyak rintangan dan jalan yang ditempuh sangat jauh, dia tetap semangat untuk datang menuntut ilmu di sekolahnya. Sikap ini sangat sesuai dengan identitas kebangsaan. Sikap pantang menyerah, memiliki komitmen dan etos kerja yang baik merupakan syarat untuk meraih kesuksesan. Semangat dan pandangan hidup ke depan akan membuat seseorang mampu melampaui masa sulit dalam menempuh pendidikan sebagaimana yang dicita-citakan. Sebagaimana dijelaskan dalam kutipan "Dalam menggapai cita-cita, hendaknya tidak mudah menyerah atau putus asa, walau cita-cita itu tidak mudah diraih dan diwujudkan sesuai keinginan. Berusahalah sekuat tenaga untuk meraih semua mimpi dan cita-cita walau dalam himpitan ekonomi dan keterbatasan" ( Hirata 2008: 472).

Pada masa ini juga berkembang penceritaan yang Islami. Fiksi Islami yang dipelopori oleh para penulis 
Forum Lingkar Pena (FLP) dan berhasil menjadi bacaan alternatif yang lebih sehat bagi masyarakat. Di antara karya para penulis FLP, seperti karya Asma Nadia, Pipiet Senja, dan Habiburrahman ElShirazy. Bahkan, novel Ayat-Ayat Cinta-nya Habiburrahman El-Shirazy telah menjadi best seller. Di antara karya-karyanya adalah Ayat-Ayat Cinta (telah dibuat versi filmnya, 2004), Di Atas Sajadah Cinta (telah disinetronkan Trans TV, 2004), Ketika Cinta Berbuah Surga (2005), Pudarnya Pesona Cleopatra (2005), Ketika Cinta Bertasbih (2007), Ketika Cinta Bertasbih 2 (Desember, 2007) Dalam Mihrab Cinta (2007), Bumi Cinta, (2010) dan The Romance.

Dalam Ayat-Ayat Cinta dominan mengangkat masalah keagamaan, khususnya Islam. Novel ini menceritakan kehidupan mahasiswa Indonesia yang sedang menuntut ilmu di Al Azhar, Kairo. Melalui tokoh Fahri, seorang yang mencari ilmu dengan belajar membaca Al Quran. Seperti yang diungkapkannya: "Aku sedikit ragu mau membuka pintu. Hatiku ketar-ketir. Angin sahara terdengar mendesau-desau. Keras dan kacau. Tak bisa dibayangkan betapa kacaunya di luar sana. Panas disertai gulungan debu yang beterbangan. Suasana yang jauh dari nyaman. Namun, niat harus dibulatkan (E1 Shirazy 2004:18). Hal itu menggambarkan bahwa mencari ilmu di Mesir tidak mudah karena harus melawan panasnya suhu udara. Hal itu merupakan wujud dari sikap tawakal. Tawakal adalah sifat menyerahkan diri kepada Allah SWT, sehingga tidak ada keraguan dalam menjalankan sesuatu. Sikap ini sangat bagus untuk menguatkan identitas kebangsaan. Orang yang penuh tawakal maka ia akan siap menghadapi segala rintangan dan hambatan yang menimpahnya. Orang yang bertawakal juga memiliki kesabaran untuk menerima apapun yang menimpahnya. Segala sesuatu yang menimpah dianggap sebagai cobaan yang harus ikhlas diterimanya.

\section{Simpulan}

Peta sastra Indonesia sangat berkaitan dengan sejarah, baik sejarah bangsa maupun sejarah sastra Indonesia sendiri. Berdirinya Boedi Oetomo, Sumpah Pemuda 1928, Masa Pendudukan Jepang, Indonesia Merdeka, Masa Pemberontakan dengan meletusnya G30S/PKI, hingga terjadinya reformasi sangat mempengaruhi karya-karya sastra Indonesia yang lahir pada masa-masa tersebut. Berdasarkan pendekatan tema universal yang dipengaruhi ideologi, sosial, budaya, dan politik maka periodisasi sejarah sastra Indonesia, yaitu: Angkatan 20 (Balai Pustaka), Angkatan 33 (Pujangga Baru), Angkatan 45 (Perjuangan), Angkatan 66 (Pergolakan), Angkatan 80 (Romantisme), dan Angkatan 98 (Reformasi). Adapun identitas kebangsaan setiap angkatan beragam sesuai dengan nilai-nilai yang terkandung di dalam karya-karya sastra pada zamannya. Pada Angkatan 20 identitas kebangsaan ditunjukkan dengan keinginan untuk merdeka, menjadi tumpah darah yang berdaulat selalu disuarakan melalui karya-karya sastra Indonesia pada masa ini. Hal ini adalah wujud dari cinta tanah air dan perjuangan untuk melepaskan belenggu kekuasaan penjajah. Pada Angkatan 33 ada usaha untuk membebaskan dari kebiasaan lama yang membelenggu. Ada kesadaran bahwa kedudukan perempuan sama pentingnya dengan laki-laki. Pada Angkatan 45 identitas kebangsaan ditunjukkan dengan mempertahankan kemerdekaan bangsa Indonesia yang telah diraih. Di samping itu, sifat mandiri, pantang menyerah, nasionalisme, dan patriotism, keteladanan juga ditunjukkan sebagai usaha untuk mencapai tujuan hidup yang dicita-citakan. Pada Angkatan 66 identitas kebangsaan ditunjukkan dengan jiwa patriotisme, berjuang tanpah pamrih, nasionalisme, membela kebenaran, dan kejujuran. Pada Angkatan 80 terdapat sikap patuh dan hormat pada keluarga, ikhlas, juga menjadi kebanggaan keluarga. Hal-hal tersebut juga merupakan identitas kebangsaan yang perlu ditumbuhkembangkan dan selalu dijaga keberadaannya untuk memperkuat persatuan, tanpa itu akan runtuh nilai-nilai peradaban dan kebudayaan di dalamnya. Pada Angkatan 98 mencerminkan eksistensi pengarang, ada kebebasan dalam berkreativitas untuk bersastra. Nilai perjuangan, pantang menyerah, relegius merupakan identitas utama dalam karya-karya sastra angkatan ini 


\section{Daftar Pustaka}

Agni B (2009) Sastra Indonesia: Pantun, Puisi, Majas, Peribahasa, Kata Mutiara. Jakarta: Hi-Fest Publishing.

Alisyahbana ST (2006) Layar Terkembang. Jakarta: Balai Pustaka.

Darma B (1992) Prasasti, Majalah Ilmu Bahasa dan Seni Nomor 9 Tahun III Januari 1992. Surabaya: IKIP Surabaya Press.

El Shirazy H (2008) Ayat Ayat Cinta. Jakarta Selatan: Republika

Hirata A (2008) Laskar Pelangi. Yogyakarta: Bentang.

Jassin HB (2013) Angkatan 66: Prosa dan Puisi. Jakarta: Gunung Agung.

Luxemburg JV, Bal M, Westseijn WG, \& Hartoko D (1992) Pengantar Ilmu Sastra. Jakarta: Gramedia. Kayam U (2001) Para Priyayi. Jakarta: Gramedia.

Krippendoerff K (1993) Analisis Isi: Pengantar Teori dan Metodologi.Jakarta: Raya Grafindo Persada.

Maolani RA \& Cahyana U (2015) Metodologi Penelitian Pendidikan. Jakarta: PT. Raja Grafindo Persada.

Moleong LJ (1991) Metodologi Penelitian Kualitatif. Bandung: PT. Remaja Rosda Karya.

Nasution J (1996) Penelitian Masyarakat. Bandung: Intermasa.

Nursasongko P (2008) Individualisme Angkatan 45. [Diakses 10 Maret 2010]. http:// www.radenpekit. wordpress.com/2008/04/08/individualisme-angkatan-45/.

Pradopo RD (1995a) Beberapa Teori, Metode Kritik, dan Penerapannya. Yogyakarta: Pustaka Pelajar. PradopoRD (1995b) Pengkajian Puisi. Yogyakarta: Gajah Mada University Press.

Rosidi A (1998) Ikhtisar Sejarah Sastra Indonesia. Bandung: Binacipta.

Soelarto B (1964) Domba-domba Revolusi. Jakarta: Nusantara.

Srengenge S (ed) (2004) Prosa: Yang Jelita yang Bercerita. Jakarta: Metafor Publising.

Sugiyono (2013) Metode Peneltian Pendidikan. Bandung: Alfabeta.

Sumardjo J (1992) Perkembangan Teater Modern dan Sastra Drama Indonesia. Bandung: Citra Aditya Bakti.

Sunarto (2001) Metodologi Penelitian Sosial dan Pendidikan (Pendekatan Kuantitatif dan Kualitatif). Surabaya: Unesa University Press.

Supratno H (1998) Wayang Sasak lakon Dewi Rengganis dalam Konteks Perubahan Masyarakat di Lombok (Kajian Sosiologi Kesenian). Disertasi. Surabaya: PPs Unair.

Tohari A (2004) Ronggeng Dukuh Paruk. Jakarta: PT. Gramedia Pustaka Utama.

Waluyo HJ (1987) Teori dan Apresiasi Puisi. Jakarta: Erlangga.

Wuradji (2001) Sosiologi Sastra. Jakarta: P2LPTK. 